\title{
Fibrinogen binds to nontoxigenic and toxigenic Corynebacterium diphtheriae strains
}

\author{
Priscila Soares Sabbadini ${ }^{1}$, Marcia Rocha Novais Genovez ${ }^{1}$, Cecília Ferreira da Silva ${ }^{1}$, \\ Thelma Lúcia Novaes Adelino', Cintia Silva dos Santos', Gabriela Andrade Pereira', \\ Prescilla Emy Nagao², Alexandre Alves de Souza de Oliveira Dias ${ }^{3}$, \\ Ana Luiza Mattos-Guaraldi ${ }^{1 /+}$, Raphael Hirata Júnior ${ }^{1}$
}

\author{
'Laboratório de Difteria e Corineformes de Importância Médica, Faculdade de Medicina ${ }^{2}$ Instituto de Biologia Roberto Alcântara Gomes, \\ Universidade do Estado do Rio de Janeiro, Av. 28 de Setembro 87/Fundos 3o andar, 20551-030 Rio de Janeiro, RJ, Brasil \\ ${ }^{3}$ Instituto Nacional de Controle de Qualidade em Saúde-Fiocruz, Rio de Janeiro, RJ, Brasil
}

The production of fibrinous exudates may play an important role in determining the outcome of bacterial infection. Although pseudomembrane formation is a characteristic feature of diphtheria, little is known about the fibrinogen (Fbn)-binding properties of Corynebacterium diphtheriae strains and the influence of the gene that codes for diphtheria toxin (tox gene) in this process. In this study we demonstrated the ability of $\mathrm{C}$. diphtheriae strains to bind to Fbn and to convert Fbn to fibrin. Bacterial interaction with rabbit plasma was evaluated by both slide and tube tests. Interaction of microorganisms with human Fbn was evaluated by both enzyme linked immunosorbent assay (ELISA) and fluorescein isothiocyanate-conjugated (FITC) Fbn binding assays. Nontoxigenic and toxigenic strains formed bacterial aggregates in the presence of plasma in the slide tests. The ability to convert Fbn to a loose web of fibrin in the plasma solution in the tube tests appeared to be a common characteristic of the species, including strains that do not carry the tox gene. Fbn binding to C. diphtheriae strains occurred at varying intensities, as demonstrated by the FITC-Fbn and ELISA binding assays. Our data suggest that the capacity to bind to Fbn and to convert Fbn to fibrin may play a role in pseudomembrane formation and act as virulence determinants of both nontoxigenic and toxigenic strains.

Key words: Corynebacterium diphtheriae - diphtheria - fibrin - fibrinogen - pseudomembrane - nontoxigenic

Fibrinogen (Fbn) is a major protein in human plasma and is primarily involved in the coagulation cascade system through its conversion to insoluble fibrin. Fbn synthesis is dramatically upregulated during inflammation or under exposure to stresses such as systemic infections. Both Fbn and fibrin play overlapping roles in blood clotting, fibrinolysis, inflammatory response, cellular and matrix interactions and wound healing. Many bacterial pathogens exploit mechanisms involved in coagulation systems to colonize exposed tissue matrix proteins or evade immune mechanisms of bacterial clearance (Doolittle 1984, Lantz et al. 1985, Mosesson 2005, Sun 2006). The production of fibrinous exudates may play an important role in determining the outcome of bacterial infection. Large numbers of bacteria are sequestered within fibrin matrices, thereby retarding bacterial spread throughout the tissues and into the bloodstream. This process is advantageous to the host

Financial support: INCA, FAPERJ, CNPq, SR-2/UERJ, PRONEX, PNPD (CAPES/MEC), PAPD (FAPERJ/CAPES)

PSS and MRNG contributed equally to this paper.

+Corresponding author: guaraldi@uerj.br

Received 25 January 2010

Accepted 18 May 2010 in that it lessens early rapid mortality. However, bacteria sequestered within fibrin deposits are protected from normal host defenses, thereby permitting unopposed proliferation (Rotstein 1992).

Coagulase is a bacterial enzyme that reacts with a cofactor found in blood plasma to catalyze the formation of fibrin from Fbn. It is produced by most of the virulent strains of staphylococci (Duthie 1954) and by Yersinia pestis (Beesley et al. 1967, Rivera et al. 2007). This activity is also a common characteristic of the Gram-positive, rod-shaped species Erysipelothrix rhusiopathiae (Tesh \& Wood 1988). Nevertheless, coagulase activity is not ordinarily reported as a property of Corynebacterium species, including Corynebacterium diphtheriae (MacFaddin 2000).

The main pathognomonic sign in case definition of diphtheria is still the formation of a pseudomembrane that usually covers the posterior pharynx and tonsils, which may also extend to the larynx and lower respiratory tract. The disease can involve almost any mucous membranes or skin surfaces (Hadfield et al. 2000). Although the severity of the disease is usually related to the extent of the local infection, the potential role of these pseudomembranes in the maintenance and/or circulation of endemic and epidemic clones of $C$. diphtheriae is still uncharacterized.

Respiratory diphtheria has an insidious onset accompanied by the formation of a pseudomembrane composed of bacteria, necrotic epithelial and inflammatory 
cells embedded in a fibrin matrix, which adheres tightly to the underlying tissue (Hadfield et al. 2000). Diphtheria toxin is generally considered the major factor responsible for local cellular destruction and accumulated debris and fibrin (Mortimer \& Wharton 1999), suggesting that the presence of bacteriophages carrying the diphtheria toxin gene (tox) is essential for pseudomembrane formation. Although fibrin deposition (pseudomembrane formation) is a characteristic feature of diphtheria, little is known about the Fbn-binding properties and fibrin web formation activity of $C$. diphtheriae strains and the influence of the tox gene in these processes.

Strains of $C$. diphtheriae that do not produce diphtheria toxin are still frequently considered non-virulent. However, the association of nontoxigenic strains with localized disease and with cases of invasive infection has become recognized, particularly with endocarditis (Gubler et al. 1998, Galazka 2000, Mattos-Guaraldi et al. 2000, Kanungo et al. 2002, Gomes et al. 2009). Various authors share the opinion that nontoxigenic strains may be responsible for pharyngitis and should be treated (Jephcott et al. 1975, Wilson 1995, Rakhmanova et al. 1997, Bonnet \& Begg 1999). However, it is also emphasized that additional studies are still required to obtain more complete information on the pathogenicity or copathogenicity of nontoxigenic $C$. diphtheriae associated with cases of infection in the respiratory tract (Reacher et al. 2000, Gomes et al. 2009).

A complete understanding of the cellular and noncellular aspects of the host response to $C$. diphtheriae infection will suggest novel strategies both to treat and to prevent the development of diphtheria, along with infections caused by nontoxigenic $C$. diphtheriae strains and their attendant consequences. This study was designed to determine the Fbn-binding activity and the ability to convert Fbn to fibrin of nontoxigenic and toxigenic $C$. diphtheriae strains.

\section{MATERIALS AND METHODS}

Bacterial strains, toxigenicity testing and growth conditions - Nontoxigenic ATCC $27010\{[$ C7 s (-) tox-] type strain and toxigenic homologous ATCC 27012 [C7 $\mathrm{s}$ (beta) tox +] $\}$, in addition to toxigenic CDC-E8392 (sucrose-non-fermenting) and TR241 (sucrose-fermenting) C. diphtheriae subsp. mitis strains, were used in this study. Staphylococcus aureus ATCC 25923 and Staphylococcus epidermidis ATCC 12228 were included in coagulase reactions as positive and negative controls, respectively.

The toxigenicity of $C$. diphtheriae strains was confirmed by the Elek test, by polymerase chain reaction (PCR) using a primer pair targeted to a portion of fragment A of tox gene (PCR-DTA; $258 \mathrm{bp}$ ) and by the "goldstandard" Vero cell cytotoxicity assay (Pallen et al. 1994, Efstratiou et al. 1998) (Table).

Stock cultures were maintained as a suspension in $10 \%(\mathrm{w} / \mathrm{v})$ skim milk containing $25 \%(\mathrm{v} / \mathrm{v})$ glycerol at $-80^{\circ} \mathrm{C}$. During experiments, microorganisms were maintained in Trypticase Soy Broth or Agar (TSB or TSA; Difco) for $48 \mathrm{~h}$ at $37^{\circ} \mathrm{C}$.
Bacterial interaction with rabbit plasma - Interaction of microorganisms with fresh and sterile EDTA (ethylenediaminetetraacetic sodium salt)-chelated rabbit plasma (Ebe Farma Biológica e Agropecuária) was evaluated by both slide and tube tests based on procedures previously described for S. aureus (Christensen et al. 1983, MacFaddin 2000, Gomes et al. 2009). Bacterial morphology was checked by staining positive tests with crystal violet. Experiments were performed in triplicate.

A modification of the slide test (also termed the bound coagulase or plasma clumping test) was performed to avoid bacterial autoaggregation in physiologic saline $[0.85 \%(\mathrm{w} / \mathrm{v}) \mathrm{NaCl}]$ by $C$. diphtheriae strains. Briefly, microorganisms previously grown in TSA were suspended in minimal essential medium (MEM; Sigma) to a concentration corresponding to the McFarland nephelometer standard number 6. A loop full of bacterial suspension was placed on a clear, clean glass slide and gently mixed with a loop full of pretested, fresh, EDTA-chelated rabbit plasma that was undiluted or diluted 1:5 or 1:10 in MEM. The results were considered positive when immediate formation (5-20 s) of macroscopic precipitate with the appearance of white clumps was detected and negative if no visible clumping occurred within 3-4 min.

The tube coagulase test (which detects bound and free coagulase activities) was performed based on procedures described for $S$. aureus strains, with bacterial cells grown in TSA. Tests were performed in $9 \times 100 \mathrm{~mm}$ glass tubes with EDTA-chelated rabbit plasma diluted in phosphate buffered saline (PBS) to 1:4. A positive test for coagulase production resulted in a clotting or a loose web of fibrin in the plasma solution. Any degree of fibrin deposition was considered a positive test due to the absence of parameters for $C$. diphtheriae in this assay. Results were reported across a range $0-4+$, 0 meaning the plasma remained liquid (no coagulase activity) and 4+ meaning the plasma completely hardened (the consistency of an agar) due to strong coagulase activity. The coagulase reactions were performed at $37^{\circ} \mathrm{C}$ in aerobic or capnophilic (under incubation of test tubes inside a candle jar) environments and read until $24 \mathrm{~h}$ post incubation. All "0" results were incubated at room temperature for $24 \mathrm{~h}$. Positive $(4+, S$. aureus) and negative $(0, S$. epidermidis $)$ controls were included in the study.

Fluorescein isothiocyanate-conjugated (FITC) Fbn binding assay - Human Fbn (Sigma) was labelled with FITC by methods previously described (Harlow $\&$ Lane 1988, Hirata et al. 2004). Briefly, Fbn suspension $(8 \mathrm{mg} / \mathrm{mL}$ in $0.1 \mathrm{M}$ sodium carbonate) labeled with $89 \mu \mathrm{L}$ FITC solution $\left(1 \mathrm{mg} \mathrm{mL}^{-1}\right.$ in DMSO) was incubated for $8 \mathrm{~h}$ at $4^{\circ} \mathrm{C}$ in the dark. Thereafter, $50 \mathrm{mM}$ $\mathrm{NH}_{4} \mathrm{Cl}$ (final concentration) was added to the reaction. To eliminate the unbound FITC, the labelled Fbn mixture with PBS was filtered three times through 30,000Da Ultrafree filter units (Sigma). Protein concentration was determined by a modified Lowry method (Markwell et al. 1978). Aliquots of FITC-Fbn were serially diluted in PBS with $0.5 \%(\mathrm{w} / \mathrm{v})$ bovine serum albumin 
TABLE

Plasma and fibrinogen (Fbn) interactions with nontoxigenic and toxigenic Corynebacterium diphtheriae and control strains

\begin{tabular}{|c|c|c|c|c|c|}
\hline \multirow[t]{2}{*}{ Strains } & \multirow[t]{2}{*}{ Cytotoxicity $^{a}$} & \multicolumn{2}{|c|}{ Rabbit plasma } & \multicolumn{2}{|c|}{ Human Fbn } \\
\hline & & $\begin{array}{c}\text { Bacterial } \\
\text { aggregation }^{b}\end{array}$ & $\begin{array}{l}\text { Coagulase } \\
\text { activity }^{c}\end{array}$ & $\begin{array}{c}\text { Bacterial } \\
\text { fluorescence }^{d}(\mu \mathrm{g})\end{array}$ & $\begin{array}{c}\text { ELISA } \\
(\mathrm{OD} \pm \mathrm{SD})^{e}\end{array}$ \\
\hline \multicolumn{6}{|l|}{ C. diphtheriae } \\
\hline ATCC 27010 & 0 & Crude plasma & $2+$ & 62.5 & $0.078 \pm 0.0029^{f, g, h}$ \\
\hline ATCC 27012 & $>20480$ & $1: 5$ & $2+$ & 31.25 & $0.094 \pm 0.0010^{f}$ \\
\hline CDC-E8392 & 80 & $1: 10$ & $2+$ & 31.25 & $0.093 \pm 0.0031^{g, i}$ \\
\hline TR241 & 5120 & $1: 10$ & $2+$ & 7.81 & $0.104 \pm 0.0012^{h, i}$ \\
\hline Staphylococcus aureus & 0 & $1: 10$ & $4+$ & 3.91 & ND \\
\hline Staphylococcus epidermidis & 0 & 0 & 0 & $>62.5$ & ND \\
\hline
\end{tabular}

$a$ : Vero cells assays for evaluation of toxin production by $C$. diphtheriae strains. The last dilution of supernatant resulting in cytopathic effect was reported as the titer; $b$ : slide test (maximum dilution of rabbit plasma that gave a positive result); $c$ : tube test [formation of (4+) clot or (2+) fibrin pellicle within ethylenediaminetetraacetic sodium salt chelated rabbit plasma]; $d$ : minimum concentration of fluorescein isothiocyanate-conjugated-Fbn that allowed the visualization of fluorescent bacterial cells; $e$ : optical density (OD) $(\lambda$ 492) \pm standard deviation (SD). Data are from three independent experiments; samples with the same letters indicated statistically significant differences $(f, g$ and $h: \mathrm{p}<0.01 ; i: \mathrm{p}<0.05)$; ND: not determined.

(BSA) (fraction V, Sigma) and used in Fbn-bacteria binding assays as follows. Aliquots $(10 \mu \mathrm{L})$ of bacterial suspensions were dispensed in glass slides, dried at $37^{\circ} \mathrm{C}$ and fixed by heat. Two-fold dilutions (from $100 \mu \mathrm{g} / \mathrm{mL}-0.78 \mu \mathrm{g} / \mathrm{mL}$ ) of FITC-Fbn in PBS with $1 \%$ $(w / v)$ BSA were reacted with fixed bacterial cells for $30 \mathrm{~min}$ at $37^{\circ} \mathrm{C}$ in a dark chamber with high humidity. Thereafter, glass slides were washed three times with PBS, mounted in $90 \%(\mathrm{v} / \mathrm{v})$ buffered glycerin solution and examined under fluorescence microscopy with an Axioplan II Epifluorescence Microscope (Zeiss).

Enzyme-linked immunosorbent assay (ELISA) - Experiments were performed as described by Harlow and Lane (1988) using microorganisms previously washed three times with PBS and resuspended in $0.1 \mathrm{M}$ carbonate buffer, $\mathrm{pH} 9.6$ at a concentration of approximately $10^{8} \mathrm{CFU} / \mathrm{mL}\left[0.2 \mathrm{OD}_{660 \mathrm{~nm}}\right.$ in a B295II spectrophotometer (Micronal)]. Each well of flat-bottomed microtitre plates (Nunc-Immuno MaxiSorb) were coated with $100 \mu \mathrm{L}$ bacterial suspensions for $1 \mathrm{~h}$ at $37^{\circ} \mathrm{C}$ and overnight at $4{ }^{\circ} \mathrm{C}$. The wells were treated with PBS with $1 \%$ $(\mathrm{w} / \mathrm{v})$ BSA and $0.05 \%(\mathrm{w} / \mathrm{v})$ Tween 20 (PBST-BSA) for 1 $\mathrm{h}$ at $37^{\circ} \mathrm{C}$ and washed three times with PBST. Aliquots of Fbn solution in PBST-BSA $(50 \mu \mathrm{g} / \mathrm{mL})$ were added to each well and the microplates were incubated for $1 \mathrm{~h}$ at $37^{\circ} \mathrm{C}$. Any unbound protein was removed by washing the wells with PBST. Bacterial interaction with Fbn was revealed with mouse monoclonal IgM anti-human Fbn (MAB; Sigma) and peroxidase-labelled rabbit anti-mouse IgM (Sigma) antibodies. Standard curves were performed in triplicate with an Fbn range from $1-50 \mu \mathrm{g} / \mathrm{mL}$. The intensity of Fbn binding by $C$. diphtheriae strains was expressed in $\mathrm{OD}_{492}$ values (Bio-Rad Model 550 spectrophotometer) and compared statistically by the Tukey test using GraphPad Prism. Differences were considered significant at $\mathrm{p}<0.05$.

\section{RESULTS}

Interaction of $C$. diphtheriae strains with rabbit plasma - The results of both slide and tube coagulase tests performed with rabbit plasma are displayed in Table. Rabbit plasma induced bacterial aggregation, suggesting the presence of a clumping factor-like activity on the surface of $C$. diphtheriae cell walls. Clumping factor-like activity was observed for all $C$. diphtheriae strains tested, including the nontoxigenic ATCC 27010 strain, but at different levels. The nontoxigenic ATCC 27010 strain formed bacterial clumps only in the presence of crude plasma. The parental toxigenic ATCC 27012 strain showed a higher affinity to rabbit plasma (1:5 dilution) than did the nontoxigenic ATCC 27010 type strain, suggesting that the presence of the tox gene, expressed as cytotoxicity and confirmed by PCR assays (Table), favored plasma-mediated aggregation of bacterial cells. The highest affinity for rabbit plasma (1:10 dilution) was observed for both the toxigenic sucrose-fermenting TR241 strain and the non-sucrose-fermenting CDC-E8392 strain.

Standardized procedures of the tube test indicated that the web formation of EDTA-chelated rabbit plasma by $C$. diphtheriae strains was detected when using plasma diluted 1:4 in 9 × $100 \mathrm{~mm}$ glass tubes and incubation at $37^{\circ} \mathrm{C}$ under capnophilic conditions for at least $6 \mathrm{~h}$. Positive and negative results of coagulase tests performed under these experimental conditions were also observed for the $S$. aureus and S. epidermidis control strains, respectively.

The tube test reaction yielded rabbit plasma completely hardened with the consistency of an agar (4+; strong positive coagulase activity) only for the S. aureus control strain, while all $C$. diphtheriae strains tested formed a loose web of fibrin in the plasma solution, (2+; positive activity for fibrin web formation). There was no 


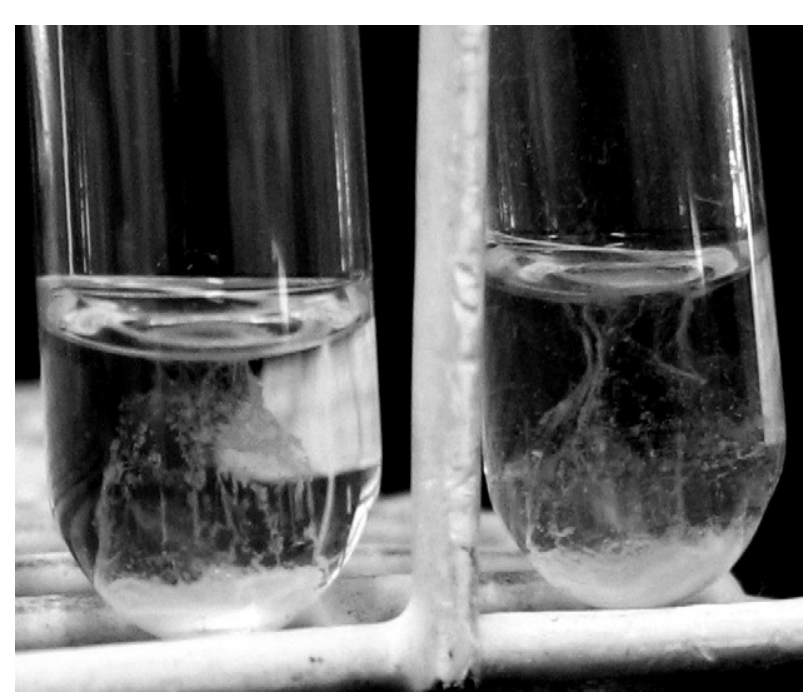

Fig. 1: micrograph illustrating positive coagulase activity of Corynebacterium diphtheriae strains in tube tests. The ability to convert fibrinogen to fibrin is represented by the formation of a loose web of fibrin embedded in plasma for both C. diphtheriae (right) nontoxigenic ATCC 27010 and (left) toxinogenic ATCC 27012 strains. Magnification 1000X.
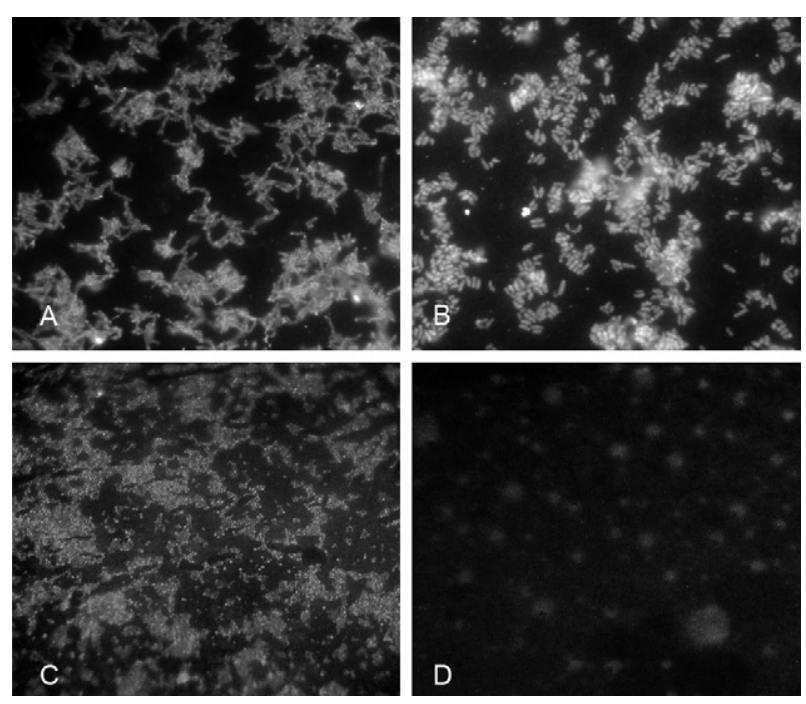

Fig. 2: micrographs showing fluorescein isothiocyanate-conjugated labelled-human fibrinogen binding reaction with homologous Corynebacterium diphtheriae (A) nontoxigenic ATCC $27010(62.5 \mu \mathrm{g})$ and (B) toxinogenic ATCC $27012(31.25 \mu \mathrm{g})$ strains; (C) Staphylococcus aureus ATCC 25923 (positive control) and (D) Staphylococcus epidermidis ATCC 12228 (negative control) $(100 \mu \mathrm{g})$. Magnification 1000X.

correlation between Fbn-binding activity and sucrose fermentation biotype (Table). The ability of a C. diphtheriae strains that do not carry the tox gene to convert Fbn to fibrin is illustrated in Fig. 1.

Interaction of C. diphtheriae strains with human Fbn - Micrographs showing FITC-Fbn binding to homologous nontoxigenic and toxigenic $C$. diphtheriae strains are presented in Fig. 2. Fbn binding to $C$. diphtheriae strains occurred at varying intensities (Table). Human Fbn bound with higher affinity to the toxigenic ATCC 27012 strain $(31.25 \mu \mathrm{g})$ than with the nontoxigenic homologous ATCC 27010 strain $(62.5 \mu \mathrm{g})$. Human Fbn bound with the highest affinity $(7.81 \mu \mathrm{g})$ to the TR241 strain, followed by the CDC-E8392 $(31.25 \mu \mathrm{g})$ and ATCC 27012 toxigenic strains $(31.25 \mu \mathrm{g})$.

The results of the ELISA experiments showed that human Fbn bound with less affinity to the nontoxigenic strain ATCC $27010(p<0.01)$ than to any of the three toxigenic strains tested (Table). Human Fbn bound with greater affinity to the toxigenic and sucrose-fermenting TR241 strain $(p<0.05)$ than to the toxigenic and nonsucrose-fermenting CDC-E8392 strain.

\section{DISCUSSION}

The Fbn polymerisation process seems not only to take place in solution but also to lead to the formation of a fibrin layer on the bacterial cell wall itself. Bacterial coagulase may be present in two forms: bound coagulase (found only on the surface of cell walls) and free coagulase (present in culture supernatant) (Duthie 1954). Bound coagulase, or clumping factor, detected by the slide procedure adsorbs Fbn from the plasma and alters it so that it precipitates onto bacterial surfaces, causing bacteria to clump and resulting in cell agglutination. In contrast to S. aureus (Dickinson et al. 1995, MacFaddin 2000), S. epidermidis strains have the ability to adhere weakly to Fbn and express clumping activity, but they do not express free coagulase activity, detected by the tube procedure, which would lead to fibrin clotting (Christensen et al. 1983, Nilsson et al. 1998). The present data show that $C$. diphtheriae strains may bind Fbn onto their surface, which may be an efficient trait to avoid phagocytosis, as previously described with other Gram-positive pathogens (Schubert et al. 2002, Rennermalm et al. 2004, Pierno et al. 2006). Bacterial aggregation by nontoxigenic ATCC 27010 was observed only in the presence of crude chelated plasma, whereas the other strains also expressed bacterial aggregates with diluted plasma, suggesting qualitative and/or quantitative differences in the expression of clumping activity by $C$. diphtheriae. Nevertheless, it must be noted that in total rabbit plasma, other proteins/glycoproteins, such as antibodies generated by microbiota, may also interact with bacterial surfaces, contributing to bacterial aggregation.

Like $S$. aureus, $C$. diphtheriae strains are capable of expressing clumping factor-like and free coagulase activities, but at lower levels. Also similar to $S$. aureus, C. diphtheriae strains express free coagulase activity, leading to fibrin web formation. Not only toxigenic strains but also nontoxigenic $C$. diphtheriae strains can adhere to Fbn and convert Fbn to fibrin, leading to the formation of semiflexible polymer-like network.

Underneath the pseudomembrane, the connective tissue consists of a highly vascularized sheet, favoring the absorption of diphtheria toxin. In addition to clot formation, fibrin and other molecules associated with the neo-formed extracellular matrix and cytokines produced locally by the inflammatory process may be involved in the proliferation of endothelial cells (Liu 
et al. 1990, Tonnesen et al. 2000). Conditions of iron deficiency improve the ability of $C$. diphtheriae strains to adhere to HEp-2 cells and agglutinate human erythrocytes, partially due to changes in the glycosylation pattern of sugar residues expressed on the bacterial surface (Moreira et al. 2003). Thus, the formation of the pathognomonic signs of diphtheria, along with the toxicity to the host, depends on the expression of bacterial factors of particular clones and/or environmental conditions observed during the infectious processes.

Differing expression of surface saccharides between non-sucrose-fermenting and sucrose-fermenting biotypes have been observed for $C$. diphtheriae, affecting bacterial hydrophobicity, agglutination to human erythrocytes and adherence to glass surfaces (MattosGuaraldi et al. 2000). Expression of a capsular polysaccharide of $S$. aureus masks clumping factor A, a protein anchored to the cell wall that is responsible for the adherence of $S$. aureus to different substrates, including human Fbn (Risley et al. 2007). We found that Fbn bound with less affinity to the CDC-E8392 nonsucrose-fermenting strain than to the TR241 sucrosefermenting isolate. It is also possible that the expression of surface polysaccharides may interfere with the interaction of $C$. diphtheriae strains with human Fbn.

During the post-vaccine era, toxigenic $C$. diphtheriae strains have been associated with cases of non-toxic catarrhal disease and non-toxic membranous disease, in addition to toxic membranous disease (Glinyenko et al. 2000, Quick et al. 2000). Differences in the abilities to bind to and to convert Fbn to fibrin may partially explain differences in the extent of pseudomembrane formation by $C$. diphtheriae strains, including cases of catarrhal diphtheria. Therefore, the data of the present study may also help to explain why nontoxigenic strains may cause pharyngitis (Jephcott et al. 1975, Wilson 1995, Rakhmanova et al. 1997, Bonnet \& Begg 1999).

Many pathogenic bacteria can interact with Fbn and manipulate its biology (Rivera et al. 2007). Our data indicate that $C$. diphtheriae should be included in this group of human pathogens, given that all strains tested showed the ability to bind Fbn and to convert Fbn to fibrin, regardless of the presence of the tox gene and toxin production. Further, they suggest that $C$. diphtheriae expresses Fbn-binding adhesins that are not encoded by the beta phage genome. However, the nontoxigenic strain ATCC 27010 interacted less intensely $(p<0.01)$ with human Fbn than did its bacteriophage-infected-derived clone ATCC 27012 , suggesting that the expression of beta phage genes may favor the expression of Fbn ligands.

Additional studies will be necessary to determine whether $C$. diphtheriae expresses a Fbn-binding microbial surface components recognizing adhesive matrix molecules adhesin, as observed for $S$. aureus (Walsh et al. 2004) and Enterococcus faecalis (Sillanpää et al. 2009). Similar to observations with other human pathogens (Kanclerska et al. 1990, Ní Eidhin et al. 1998, Rindi et al. 2006, Rosenau et al. 2007), qualitative and quantitative differences in the expression of Fbn-binding adhesins may contribute to variations in the virulence potential of $C$. diphtheriae strains.

\section{ACKNOWLEDGEMENTS}

To Jorge Ari da Cruz, for technical assistance.

\section{REFERENCES}

Beesley ED, Brubaker RR, Janssen WA, Surgalla MJ 1967. Pesticins. 3. Expression of coagulase and mechanism of fibrinolysis. $\mathrm{J} \mathrm{Bac-}$ teriol 94: 19-26.

Bonnet JM, Begg NT 1999. Control of diphtheria: guidance for consultants in communicable disease control. World Health Organization. Commun Dis Public Health 2: 242-249.

Christensen GD, Parisi JT, Bisno AL, Simpson WA, Beachey EH 1983. Characterization of clinically significant strains of coagulase-negative staphylococci. J Clin Microbiol 18: 258-269.

Dickinson RB, Nagel JA, McDevitt D, Foster TJ, Proctor RA, Cooper SL 1995. Quantitative comparison of clumping factor- and coagulase-mediated Staphylococcus aureus adhesion to surface-bound fibrinogen under flow. Infect Immun 63: 3143-3150.

Doolittle RF 1984. Fibrinogen and fibrin. Annu Rev Biochem 53: 195-229.

Duthie ES 1954. Evidence for two forms of staphylococcal coagulase. J Gen Microbiol 10: 427-436.

Efstratiou A, Engler KH, Dawes CS, Sesardic D 1998. Comparison of phenotypic and genotypic methods for detection of diphtheria toxin among isolates of pathogenic corynebacteria. J Clin Microbiol 36: 3173-3177.

Galazka A 2000. The changing epidemiology of diphtheria in the vaccine era. J Infect Dis 181 (Suppl. 1): S2-9.

Glinyenko VM, Abdikarimov ST, Firsova SN, Sagamonjan EA, Kadirova R, Nuorti JP, Strebel PM 2000. Epidemic diphtheria in the Kyrgyz Republic, 1994-1998. J Infect Dis 181 (Suppl. 1): S98-103.

Gomes DL, Martins CA, Faria LM, Santos LS, Santos CS, Sabbadini PS, Souza MC, Alves GB, Rosa AC, Nagao PE, Pereira GA, Hirata R Jr, Mattos-Guaraldi AL 2009. Corynebacterium diphtheriae as an emerging pathogen in nephrostomy catheter-related infection: evaluation of traits associated with bacterial virulence. J Med Microbiol 58: 1419-1427.

Gubler J, Huber-Schneider C, Gruner E, Altwegg M 1998. An outbreak of nontoxigenic Corynebacterium diphtheriae infection: single bacterial clone causing invasive infection among Swiss drug users. Clin Infect Dis 27: 1295-1298.

Hadfield TL, McEvoy P, Polotsky Y, Tzinserling VA, Yakovlev AA 2000. The pathology of diphtheria. J Infect Dis 181 (Suppl. 1): S116-120.

Harlow E, Lane D 1988. Antibodies: a laboratory manual, 1st ed., Cold Spring Harbor Laboratory Press, New York, 726 pp.

Hirata R Jr, Souza SM, Rocha-de-Souza CM, Andrade AF, MonteiroLeal LH, Formiga LC, Mattos-Guaraldi AL 2004. Patterns of adherence to HEp-2 cells and actin polymerisation by toxigenic Corynebacterium diphtheriae strains. Microb Pathog 36: 125-130.

Jephcott AE, Gillespie EH, Davenport C, Emerson JW, Moroney PJ 1975. Non-toxigenic Corynebacterium diphtheriae in a boarding school. Lancet 1: 1025-1026.

Kanclerska J, Kanclerski K, Hryniewicz W 1990. The role of surface structures of Streptococcus agalactiae in adhesion to epithelial cells. Med Dosw Mikrobiol 42: 101-107.

Kanungo R, Vijayalakshmi N, Nalini P, Bhattacharya S 2002. Diphtheria due to non-toxigenic Corynebacterium diphtheriae: a report of two cases. Indian J Med Microbiol 20: 50-52.

Lantz MS, Switalski LM, Kornman KS, Höök M 1985. Bacteroides intermedius binds fibrinogen. J Bacteriol 163: 623-628. 
Liu HM, Wang DL, Liu CY 1990. Interactions between fibrin, collagen and endothelial cells in angiogenesis. Adv Exp Med Biol 281: 319-331.

MacFaddin JF 2000. Coagulase test. In L McGrew, Biochemical tests for identification of medical bacteria, Lippincott Williams \& Wilkins, Philadelphia, p. 105-119.

Markwell MA, Haas SM, Bieber LL, Tolbert NE 1978. A modification of the Lowry procedure to simplify protein determinations in membrane and lipoprotein samples. Anal Biochem 87: 206-210.

Mattos-Guaraldi AL, Duarte Formiga LC, Pereira GA 2000. Cell surface components and adhesion in Corynebacterium diphtheriae. Microbes Infect 2: 1507-1512.

Moreira L de O, Andrade AF, Vale MD, Souza SM, Hirata R Jr, Asad LM, Asad NR, Monteiro-Leal LH, Previato JO, Mattos-Guaraldi AL 2003. Effects of iron limitation on adherence and cell surface carbohydrates of Corynebacterium diphtheriae strains. Appl Environ Microbiol 69: 5907-5913.

Mortimer EA, Wharton M 1999. Diphtheria toxoid. In SA Plotkin, WA Orenstein, Vaccines, WB Saunders Company, Philadelphia, p. 104-157.

Mosesson MW 2005. Fibrinogen and fibrin structure and functions. J Thromb Haemost 3: 1894-1904.

Ní Eidhin D, Perkins S, Francois P, Vaudaux P, Höök M, Foster TJ 1998. Clumping factor B (ClfB), a new surface-located fibrinogen-binding adhesin of Staphylococcus aureus. Mol Microbiol 30: $245-257$.

Nilsson M, Frykberg L, Flock JI, Pei L, Lindberg M, Guss B 1998. A fibrinogen-binding protein of Staphylococcus epidermidis. Infect Immun 66: 2666-2673.

Pallen MJ, Hay AJ, Puckey LH, Efstratiou A 1994. Polymerase chain reaction for screening clinical isolates of corynebacteria for the production of diphtheria toxin. J Clin Pathol 47: 353-356.

Pierno M, Maravigna L, Piazza R, Visai L, Speziale P 2006. FbsAdriven fibrinogen polymerization: a bacterial "deceiving strategy". Phys Rev Lett 96: 028108.

Quick ML, Sutter RW, Kobaidze K, Malakmadze N, Strebel PM, Nakashidze R, Murvanidze S 2000. Epidemic diphtheria in the Republic of Georgia, 1993-1996: risk factors for fatal outcome among hospitalized patients. J Infect Dis 181 (Suppl. 1): $\mathrm{S} 130-137$.

Rakhmanova AG, Lumio J, Groundstroem KW, Taits BM, Zinserling VA, Kadyrova SN, Goltsova EY, Melnick OB 1997. Fatal respiratory tract diphtheria apparently caused by nontoxigenic strains of Corynebacterium diphtheriae. Eur J Clin Microbiol Infect Dis 16: 816-820.

Reacher M, Ramsay M, White J, De Zoysa A, Efstratiou A, Mann G, Mackay A, George RC 2000. Nontoxigenic Corynebacteri- um diphtheriae: an emerging pathogen in England and Wales? Emerg Infect Dis 6: 640-645.

Rennermalm A, Nilsson M, Flock JI 2004. The fibrinogen binding protein of Staphylococcus epidermidis is a target for opsonic antibodies. Infect Immun 72: 3081-3083.

Rindi S, Cicalini S, Pietrocola G, Venditti M, Festa A, Foster TJ, Petrosillo N, Speziale P 2006. Antibody response in patients with endocarditis caused by Staphylococcus aureus. Eur J Clin Invest 36: 536-543.

Risley AL, Loughman A, Cywes-Bentley C, Foster TJ, Lee JC 2007. Capsular polysaccharide masks clumping factor A-mediated adherence of Staphylococcus aureus to fibrinogen and platelets. J Infect Dis 196: 919-927.

Rivera J, Vannakambadi G, Höök M, Speziale P 2007. Fibrinogenbinding proteins of Gram-positive bacteria. Thromb Haemost 98: 503-511.

Rosenau A, Martins K, Amor S, Gannier F, Lanotte P, van der Mee-Marquet N, Mereghetti L, Quentin R 2007. Evaluation of the ability of Streptococcus agalactiae strains isolated from genital and neonatal specimens to bind to human fibrinogen and correlation with characteristics of the fbsA and fbsB genes. Infect Immun 75: 1310-1317.

Rotstein OD 1992. Role of fibrin deposition in the pathogenesis of intraabdominal infection. Eur J Clin Microbiol Infect Dis 11: 1064-1068.

Schubert A, Zakikhany K, Schreiner M, Frank R, Spellerberg B, Eikmanns BJ, Reinscheid DJ 2002. A fibrinogen receptor from group B Streptococcus interacts with fibrinogen by repetitive units with novel ligand binding sites. Mol Microbiol 46: $557-569$.

Sillanpää J, Nallapareddy SR, Houston J, Ganesh VK, Bourgogne A, Singh KV, Murray BE, Höök M 2009. A family of fibrinogen-binding MSCRAMMs from Enterococcus faecalis. Microbiology 155: 2390-2400.

Sun H 2006. The interaction between pathogens and the host coagulation system. Physiology (Bethesda) 21: 281-288.

Tesh MJ, Wood RL 1988. Detection of coagulase activity in Erysipelothrix rhusiopathiae. J Clin Microbiol 26: 1058-1060.

Tonnesen MG, Feng X, Clark RA 2000. Angiogenesis in wound healing. J Investig Dermatol Symp Proc 5: 40-46.

Walsh EJ, O'Brien LM, Liang X, Hook M, Foster TJ 2004. Clumping factor B, a fibrinogen-binding MSCRAMM (microbial surface components recognizing adhesive matrix molecules) adhesin of Staphylococcus aureus, also binds to the tail region of type I cytokeratin 10. J Biol Chem 279: 50691-50699.

Wilson AP 1995. The return of Corynebacterium diphtheriae: the rise of non-toxigenic strains. J Hosp Infect 30 (Suppl.): 306-312. 